\title{
Determinants of Unethical Financial Reporting: A Study of the Views of Professional and Academic Accountants in Nigeria
}

\author{
Ioraver N. Tsegba ${ }^{1}$, Jocelyn U. Upaa ${ }^{1} \&$ Simon A. Tyoakosu ${ }^{1}$ \\ ${ }^{1}$ Department of Accounting \& Finance, College of Management Sciences, Federal University of Agriculture, \\ Makurdi, Nigeria \\ Correspondence: Ioraver N. Tsegba, Department of Accounting \& Finance, College of Management Sciences, \\ Federal University of Agriculture, Makurdi, Nigeria. Tel: 234-703-768-1542. E-mail: drintse2004@ gmail.com
}

Received: March 24, 2015

Accepted: April 10, 2015

Online Published: May 25, 2015

doi:10.5539/ibr.v8n6p29

URL: http://dx.doi.org/10.5539/ibr.v8n6p29

\begin{abstract}
This study ascertained the determinants of unethical financial reporting, exploring the views of professional and academic accountants in Nigeria. The study utilized the survey design with a sample of 212 respondents drawn from a population made of professional and academic accountants resident in Benue State of Nigeria. The postulated hypotheses were tested using multinomial logistic regression, Kruskal-Wallis $H$ and Chi-square tests, and Mann-Whitney $U$ test. The empirical results evidenced, in order of severity, 'weak corporate governance', 'attempts to conceal deteriorating financial position', and 'compensation and bonus incentives' as the main determinants of unethical financial reporting. The results, however, suggested significant differences in the views of respondent groups on the identified determinants of unethical financial reporting with manifest implications on how policies aimed at addressing the phenomenon of interest would be initiated. The major recommendation of the study is the urgent need to incorporate good corporate governance systems in the overall strategies of corporations in order to curtail incidences of unethical financial reporting.
\end{abstract}

Keywords: ethics, unethical financial reporting, professional accountants, academic accountants, corporate governance, Nigeria

\section{Introduction}

Financial reports, which are used by managers to give an account of their stewardship to shareholders and other stakeholders, are expected to present a fair view of the financial position of an organization as at the time of the reports' preparation. The reports are documents that are expected to influence the decision making process of a diversity of interest groups, including shareholders, prospective investors, creditors, regulatory agencies, and men of affairs such as businessmen, politicians, labour leaders, and governments (Herbert \& Tsegba, 2013). The rising number of corporate crises, failures and scandals, such as Enron, WorldCom, Global Crossing, HIH Insurance, Ansett, Pan Pharmaceuticals, Lever Brothers, Cadbury, and Afribank, and their association with unethical financial reporting have, however, called to question, the level of reliability of financial reports as it is being perceived that such reports could be doctored and might not present the true and fair picture of the health status of the organization presenting them (Olalere, 2010).

The fears surrounding the reliability of financial reports stem from the flexibility offered by Generally Accepted Accounting Principles (GAAP) in the recording of transactions and the preparation of the reports. This flexibility accords corporate management opportunities to actively alter their financial results in some desired amount through accounting policy choice, accounting policy application, or outright fraudulent financial reporting (Mulford \& Comiskey, 2002). Financial fraud, which could be concealed in fraudulent financial reports, has been construed by the National Association of Certified Fraud Examiners (NACFE) as the 'intentional misstatement or omission of material facts or accounting data which is misleading and, when considered with all information available, would cause the reader to change or alter his or her judgement or decision (NACFE, 1993, p. 12). This definition evokes deviations emanating from pushing GAAP beyond their intended limits; it also suggests breach of ethical norms in financial reporting.

\subsection{Ethics and Financial Reporting}

Ethical issues that might be breached in financial reporting include, non-disclosure of the misdeeds of trusted 
executives of small, medium and large corporations, unreported revenues, manipulation of losses, inflated sales, and fraudulent write-offs of uncollectible accounts, unusual related-party transactions, misappropriation of assets and many other irregularities (Vanasco, 1998). Other misdeeds advocated by Vanasco (1998) typically involve complex methods for misusing, or misdirecting funds, overstating revenues, understating expenses, overstating the value of corporate assets, or under reporting existing liabilities, sometimes with the cooperation of officials in other corporations.

Historically, interest in business ethics accelerated dramatically during the 1980s and 1990s, both within major corporations and academia (Obazee, 2005). For several years, accounting ethics have been viewed as an un-important adjunct of academic and professional accounting (Olalere, 2010) with sparse attention given to them in accounting research. The tripping point is that academic articles on accounting ethics have not been construed as original, thoughtful, or rigorous (Achua, 2009). This is inspite of the increasing wave of unethical financial reporting practices across the globe on a scale that has not been contemplated before.

One of the most disturbing observations about corporate reporting scandals is that some accountants employed by the organizations and their auditors were part of the decisions that allowed these practices to continue unabated for such a relatively lengthy period of time. In Nigeria, the Cadbury crisis arose from significant and deliberate overstatement of financial statements over the years (Onu, 2007), while the Afribank case was outright cooking of the bank's books by the internal directors and external auditors (Jetuah, 2007; Onu, 2007). The fall outs from scandals relating to unethical financial reporting have had perverse impact on the accounting profession, and the users of the reports, which suggests that they stem from a systemic decline of accounting ethics over the past years.

Accounting is a profession that rests heavily on the need to exhibit a high sense of accountability and stewardship, hence the emphasis that all members be guided by professional code of conduct (Nwagboso, 2008). The diverse and increasing range of services provided by the accountant and the reported cases of corporate failures and collapses such as Enron, Global Crossing, Cadbury Nigeria Plc, Afribank Plc on a scale unprecedented in corporate history have drawn attention to ethical standards within the accounting profession. These corporate collapses have resulted in widespread disregard for the reputation of the accounting profession (Giacomino \& Akers, 2006). To combat criticisms and prevent fraudulent accounting, various organizations and governments have developed regulations and remedies for improved ethics among accounting profession.

There appears to be consensus that integrity, objectivity, professional competence, confidentiality, professional behavior, technical standards, and independence are the fundamental ethics and guidelines applicable to all accountants (see Aguolu, 2006). Any behavior that contravenes any of these could be classified as unethical.

Extant literature suggests that before the Enron and Andersen scandals, sparse attention was paid to the truthfulness of financial reporting. The general belief among the public appeared to be that financial statements of companies which had undergone the attest (audit) function would not be a subject of suspicion for misrepresenting activities. This confidence has been greatly threatened. Doubts and cynicism about current reporting practices have spread, particularly with the discoveries of fraudulent financial reporting of WorldCom, Enron, Xerox, and Waste Management. The ethics of reporting have, therefore, constituted a major challenge facing corporations across the globe.

Truthfulness of and trust in the financial reporting system depend on far more than the actions and decisions of individuals or sophisticated mechanisms for the whole system. As the Enron and Andersen events have shown (see Enderle, 2004), far-reaching failures occurred at the individual (or micro) level of top managers, directors of corporate boards, management accountants, auditors, financial analysts, other employees, and members of supervisory boards and public agencies, including politicians. Thus, while these business failures, scandals and crises were not only disappointing, given the size and public regard for the integrity of the affected companies, investor confidence was also increasingly being eroded as a consequence (see Deakin \& Konzelmann, 2004; Cohen \& Holder-Webb, 2006). Furthermore, these corporate scandals and failures raised concerns over the effectiveness of corporate governance mechanisms and corporate accountability.

It would be shortsighted to blame only individuals. The crisis has also revealed serious insufficiencies at the systemic (or macro) level. The regulatory framework did not prevent but encouraged the establishment of several crucial conflicts of interest (particularly in the auditing and investment industry), the tempting call of which could be resisted only with extraordinary moral power (Enderle, 2004). Many accounting and investment rules were vague, providing insufficient guidance in complex matters. In many instances the enforcement of the existing framework was half-hearted or even totally lacking.

In Nigeria, failures and near collapse of leading companies and banks have brought the issue of ethics in 
financial reporting to the front burner for research and discussion. In 2008, the Securities and Exchange Commission (SEC) penalized Cadbury Plc as well as Akintola Williams Delotte for accounting scandals (Achua, 2009). SEC also suspended Afroil Plc and Capital Oil Plc for different violations, including non remittance of audited financial accounts and reports as at due date (Nwagboso, 2008). Between 1994 and 2003, the Nigerian Deposit Insurance Corporation (NDIC) liquidated 36 banks in Nigeria for offences that included also unethical financial reporting.

Worried about the trend of unethical practices in financial reporting by Nigerian accountants and the auditors' inability to detect them, the Companies and Allied Matters Act, 1990 (as amended) had provided in section 359 (2), for Auditor's Report to be counter signed by a legal practitioner, ostensibly to serve as a form of control and check on the Nigerian accountant and auditor. Even though this requirement was later amended, it suggests the level to which the perceived unethical practice by Nigerian accountants and auditors was reduced to.

\subsection{Unethical Financial Reporting}

Unethical financial reporting and financial statement fraud are often used interchangeably. Razaee (2002) captures financial statements fraud in the following respects: (i) Falsification, alteration, or manipulation of material records, supporting documents, or business transactions; (ii) Material intentional misstatements, omissions, or misrepresentations of events, transitions, accounts or other significant information from which financial statements are prepared; (iii) Deliberate misapplication, intentional misinterpretation, and wrongful execution of accounting standards, principles, policies and methods used to measure, recognize, and report economic events and business transactions; (iv) Intentional omissions and disclosures or presentation of inadequate disclosures regarding accounting standards, principles, practices, and related financial information; (v) The use of aggressive accounting techniques through illegitimate earnings management; and Manipulation of accounting practices under the existing rules-based accounting standards which have become too detailed and too easy to circumvent and contain loopholes that allow companies to hide the economic substance of their performance.

Abrecht (2008) provides further insight into recipes used by management that have decided to engage in fraudulent financial reporting: (i) Overstatement of revenue; (ii) understatement of expenses; (iii) overstatement of assets; (iv) Understatement of liabilities; and (v) improper use of reserves.

\subsection{Motives for Unethical Financial Reporting}

Analyses of unethical financial reporting are anchored on three common themes, which resonate with the classical fraud theory as motivating factors for committing financial reporting fraud, namely pressure from stakeholders, opportunity emanating from weak internal control mechanisms put in place by shareholders, and rationalization. Loebbecke, Eining and Willingham (1989) have identified undue emphasis on meeting earnings targets, meeting regulatory requirements, increasing the stock prices, bolstering financial performance for pending equity or debt financing, and concealing the company's deteriorating financial condition as key pressure factors that could compel management to engage in fraudulent financial reporting.

Providing the opportunity to commit financial fraud is also one of the most important factors to be considered. The opportunity factors revolve around weak corporate governance which could be exploited to the company's advantage. As suggested by Razaee (2002) factors which induce financial fraud include undisclosed contracts made with third parties and partners, weakness of information flow among employees within the business, ignorance, indifference, and inabilities of top management, inability to assess the quality of the job employees perform, and poor audit culture. Loebbecke, Eining and Willingham (1989) have also included low financial expertise of external auditors as providing opportunities for management to engage in financial fraud. Rationalization of corporate behavior regarding unethical financial reporting could be excused away by the desire to protect the company from deteriorating financial condition which needs to be concealed from the public for fear of adverse consequences to the company.

\subsection{Objectives and Organization of the Paper}

The main objective of this study, therefore, is to ascertain the determinants of unethical financial reporting, exploring the views or perceptions of professional and academic accountants in Benue State of Nigeria. Specifically the study seeks to first ascertain, in order of severity, what professional and academic accountants consider as the main determinants of unethical behavior exhibited by accountants in financial reporting, and second establish if there are significant differences between the views expressed by professional and academic accountants on the phenomena of interest. Significant differences in the views of the key stakeholders on the subject would portend closing the knowledge gap between professional and academic accountants on what 
promotes unethical financial reporting.

This study is organized into five sections including this introduction as section one. In section two, extant theoretical and empirical literature related to the subject matter is explored. Section three presents the methodology while section four analyses the data and discusses the results. The study concludes with section five, wherein, recommendations are made for policy makers.

\section{Review of Related Literature}

This section presents the theoretical framework for the study, which is embedded in the fraud triangle theory, the fraud diamond model, the agency theory, and the stakeholder theory. The section also reviews the empirical works carried out on the phenomena of interest.

\subsection{Theoretical Framework}

The theoretical background to investigations into the determinants of unethical financial reporting is provided by Cressey's fraud triangle theory, fraud diamond theory, agency theory and stakeholder theory. Elements of the fraud triangle theory were first identified by Sutherland (1949) and further developed by Cressey (1953). The fraud triangle theory explicates the reasons why an individual becomes involved in fraud. The fraud triangle concept was adapted from criminology to accounting by Steve Albrecht (Chao \& Tan, 2007). The theory suggests that individuals become involved in fraud due to three factors, namely perceived opportunity, perceived pressure, and rationalization (see Figure 1) below.

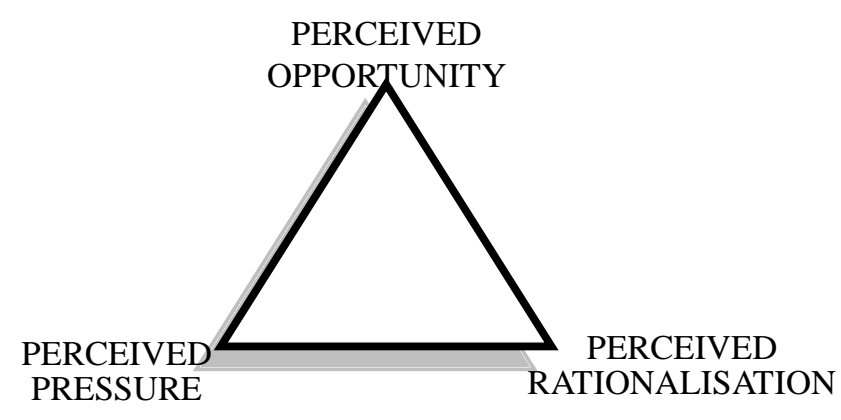

Figure 1. Classical fraud motivation model

Source: Albrecht (2008).

The first element of the fraud triangle is a perceived pressure, which can be either a positive or a negative force. From the positive angle, when goals are achievable, pressure contributes to creativity, efficiency and competitiveness. When goals are not achievable by normal means but pressure continues unabated, with career advancement, compensation and even continued employment at risk, individuals (and corporate organizations too) are most likely to resort to questionable activities that constitute fraud. The top motivators for fraud and fraudulent or unethical financial reporting have been identified as (i) personal gain (including maximizing performance bonuses and the value of stock-based compensation, (ii) Achieving short-term financial goals (either internal targets or external analysts expectation), (iii) Hiding bad news from investors and the capital markets, (iv) the desire to recoup and avoid losses, and (v) To increase or prevent a decrease in stock price (See Lowenstein \& Rick, 2008; Johnson, Ryan, \& Tian, 2009).

The second element of the fraud triangle is perceived opportunity. Financial reporting fraud cannot occur unless an opportunity is present such as inherent susceptibility of the company's accounting to manipulation and other conditions within the company that may allow a fraud to occur, commonly tagged as weak corporate governance (see Soltani, 2009). The perpetrator must believe that he or she can commit the fraud and not get caught or that if he or she gets caught, nothing serious will happen. The third element is that fraud perpetrators need a way to rationalize their actions as acceptable. The importance of the fraud triangle in explicating fraud has gained popularity and led the American Institute of Certified Public Accountants (AICPA) in 2010 to integrate the fraud triangle into its audit standards; SAS 99, Considerations of Fraud in a Financial Statement Audit, to help better train and prepare auditors to detect fraud when conducting financial statement audits.

Wolfe and Hermanson (2004) introduced the "Fraud Diamond Model" which extends the fraud triangle by inclusion of "the fraudster's capabilities". The Fraud Diamond Model suggests that many frauds would not have 
occurred without the right person with the right capabilities implementing the details of the fraud. It then suggests four observable traits and capabilities for committing fraud: a) Authoritative position or function within the organization; b) Capacity to understand and exploit accounting systems and internal control weaknesses; c) Confidence of not being detected or if caught will get out easily; and d) Capability to deal with the stress created within an otherwise good person when he or she commits fraud. The Fraud Diamond Model is presented in Figure 2 below.

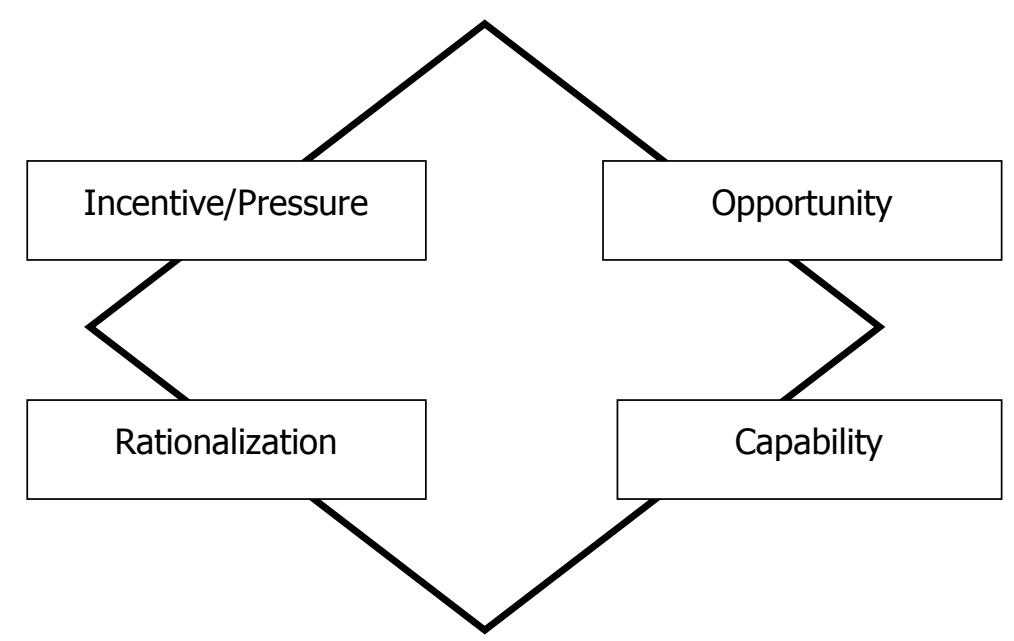

Figure 2. The fraud diamond model

Source: Wolfe and Hermanson (2004).

From a legal perspective, agency theory is a 'fiduciary relationship created by express or implied contract or by law, in which one party (the agent) may act on behalf of another party (the principal) and bind that other party by words or actions' (Garner, 2004, p. 67). The agency theory is based on economic theory; it postulates a principal-agent relationship between owners (shareholders) and executives, with top executives acting as agents whose personal interests is always at parallel with stockholder interests (see Chao \& Tan, 2007). The principal-agent relationship involves a transfer of trust and duty to the agent while assuming that the agent is opportunistic and will pursue interests, including executive fraud, which are in conflict with those of the principal. This theory, therefore, presumes tension between owners (shareholders) and entrenched managers; it also solicits for close monitoring of entrenched managers.

Two situations which inform the perverse views expressed about the principal-agent relationship are moral hazard and adverse selection. Albrecht (2008) expatiates on these situations. Moral hazard arises when the agent's action, or the outcome of that action, is only imperfectly observable to the principal. A manager, for example, may exercise a low level of effort, waste corporate resources, or take inappropriate risks. Adverse selection can arise when the agent has some private information, prior to entering into relations with the principal. Individuals with poor skills or aptitude will present themselves as having superior ones, people with low motivation will apply for the positions that involve the least supervision, and so forth.

Solutions to the agency problem emanate from the corporate governance mechanisms put in place by the shareholders. Corporate governance refers broadly to the system or structures (internal and external)-processes, rules, regulations and control mechanism-that govern the conduct of an organization for the benefits of all stakeholders. Typical solutions to the agency problem require: 1) structuring executive incentives; 2) controlling and curtailing the opportunistic behavior of the executives through a monitoring board, a task that is consummated by the audit committee; 3) ensuring that executives or managers act in the best interests of the owners by increasing the amount and quality of information available to principals, and making senior executives part owners of the firm through their compensation packages (Luhman \& Cunliffe, 2012).

The relationship between agency theory and unethical financial reporting is epitomized by the agent (executives) covering his self-pursuit activities through resort to reporting processes that are considered unethical, such as unreported revenues, manipulation of losses, inflated sales and fraudulent write-offs of uncollectible accounts.

The stakeholder theory defines organizations as multilateral agreements between the enterprise and its multiple stakeholders and the relationship between the company and its internal and external stakeholders (Jensen, 2001). 
The theory recognizes that many groups have links with the firm and are affected by decisions it management takes. In this regard the firm is seen as the nexus of implicit and explicit contracts among the participants (Fama \& Jensen, 1983), making it inappropriate to single one party above the others (Kay \& Silberton, 1995). Unlike the agency theory that places primary emphasis only on shareholders' interests, stakeholder theory places emphasis on considering the interests of all parties in a corporation which are diverse and more prone to the adverse effect of unethical financial reporting. These parties include creditors, lenders, employees and shareholders. The theory determines the legitimate interests and rights of various stakeholders (presumably going above and beyond their legal rights), and uses these as a way of determining corporate and managerial duties (Heath \& Norman, 2004).

The stakeholder theory, in particular, places pressure on management to present financial reports that would satisfy the diverse interests of the stakeholders. The presentation of such reports is bound to be faced with myriads of challenges since the users' needs may not cohere in all cases. The emerging supporting argument is that management would seek protection under available means and present financial reports that may deviate from accepted norms in order to satisfy the various interest groups.

\subsection{Empirical Review}

Researchers investigating unethical conduct in financial reporting are subsumed in what has been characterized as 'earnings management' or 'creative accounting'. The distinction between financial or fraudulent reporting and earnings management needs further exploration: while earnings management is the active manipulation of earnings towards a pre-determined target, fraudulent reporting is the intentional misstatement or omission of material facts or accounting in order to achieve some desired objectives (see NACFE, 1993; Mulford \& Comiskey, 2002).

Investigations into the causes of unethical or fraudulent financial reporting have not followed a particular order but a basic feature of the studies mentioned in this paper resonate from the classical fraud and diamond theories where pressure, opportunity and rationalization are considered the major inducing factors. Beasley, Carcello and Hermanson (1999) have identified, from an analysis of U.S. public companies, six factors which induce corporate management to engage in financial statement fraud: (1) Avoid reporting a pretax loss and to exaggerate financial performance; (2) Meet or exceed security analysts' expectations of earnings' growth; (3) Increase the stock price and create demand for issuing new shares; (4) Obtain national stock exchange listing status or meet minimum exchange listing requirements to prevent being delisted; (5) Cover up assets misappropriated for personal use; and (6) Conceal deficiencies in performance.

Some studies have provided evidence which supports Beasley, Carcello and Hermanson's (1999) position but others have introduced into the fold, more determinants of unethical financial reporting. On the supporting side, Payne and Robb (2000) also identify the need to meet or exceed security analysts' expectation of earnings growth, elimination of negative earnings surprises, and desire to promote favourable share price, as major determinants of unethical financial reporting. Roychowdhury (2006) also support the use of fraudulent reporting to avoid reporting losses.

Studies providing additional evidence on the determinants of fraudulent financial reporting include Leuz, Nanada and Wysocki (2003), Singh (2006), and Skousen, Smith and Wright (2009). For instance, Leuz, Nanada and Wysocki (2003) investigated managerial opportunistic behavior including excessive compensation for managers and asserted that such behavior ultimately reflected in the firm's earnings misstatement. They conclude that there would be an incentive to fraudulently manipulate financial reports if compensation, stock option, bonus and other performance related payments are tied to earnings. Sing (2006) conducted a study to ascertain the major causes of unethical financial reporting, amongst others, and found that delays in prosecuting fraud related cases was the most important cause of unethical financial reporting. Other factors identified by Sing's (2006) study that could cause unethical financial reporting are: protection of self-interest of auditors, poor corporate governance, and whistle blowing issues.

Skousen, Smith and Wright's (2009) study aimed at assessing the effectiveness of the theory of Cressey about the fraud risk factor framework implemented in SAS No. 99 to detect financial statement fraud. Their study developed a variable that serves as a proxy measure for pressure, opportunity and rationalization. The finding identified five pressures and two proxy opportunities that are significantly associated with cheating. The results showed that rapid asset growth, increased need for cash and external financing is positively related to the likelihood of fraud. They also discovered that the internal and external ownership and control of the board of directors is also associated with an increase in financial statement fraud. In addition, they found that the expansion of the number of independent members on the audit committee is negatively correlated with the 
occurrence of fraud.

As stated earlier, prior studies have majorly identified what could be termed as the determinants of unethical financial reporting. This approach has given insights into the subject matter but it has not addressed issues related to the levels of severity of the identified determinants. An understanding of the severity of the determinants of unethical financial reporting is necessary to enable appropriate measures to curb the menace to be put in place. There also appears to be sparse or limited evidence on what constitutes unethical financial reporting from the Nigerian perspective, a lacuna which this study seeks to fill.

\section{Methodology}

This section describes the methods adopted in the study. It specifies the research design, the population and sample, variable definition and measurement, the sources of data, and the procedures used in data collection and analysis.

\subsection{Research Design}

This study adopts exploratory and descriptive designs which have been identified as the major types of researches which can be used to study human behavior (Akpa, 2011). It uses a survey approach, a sub-type of descriptive research that is characterized by the researcher reaching out to the respondents in their natural settings to collect data. The main aim of the survey is to ascertain the views of professional and academic accountants resident in Benue State on what they consider to be the major determinants of unethical bahaviour in financial reporting. As stated earlier, knowledge of the determinants and coherence or otherwise of the views expressed by the stakeholder respondent groups is necessary if the phenomenon of interest is to be understood in greater depth.

\subsection{Population and Sample Size}

The population for the study comprised mainly professional and academic accountants resident in Benue State. The choice restriction to Benue State was due to reasons of logistics and resources (both in terms of time and money). The professional accountants are defined as members of the Institute of Chartered Accountants of Nigeria (ICAN) and members of the Association of National Accountants of Nigeria (ANAN). Accounting academics are defined in the exclusive way to incorporate accounting lecturers and postgraduate accounting students. Accounting lecturers in well-established tertiary institutions in Benue Sate of Nigeria make up the population for the study. The candidates are all the accounting lecturers in the Federal University of Agriculture Makurdi (FUAM); Benue State University (BSU), Makurdi; University of Mkar, Mkar (UMM); Fidel Polytechnic, Gboko (FPG); Benue State Polytechnic, Ugbokolo (BSPU); and the College of Education, Katsina Ala (COEKAT). The postgraduate accounting students comprised all postgraduate accounting students of FUAM and BSU. Despite the limitation of the population to Benue State, it is expected that the conclusions reached in this study will not be remarkably different from those of a wider population covering more states of Nigeria. This is underscored by the realization that accountants in the same group (professional, lecturers and students) should exhibit similar views on key areas considered to be the determinants of unethical financial reporting. The population used in this study sums up to 450 as contained in Table 1 below.

The sample size determination followed the method described by Akpa (2011) for finite data, by applying the Yaro Yamani sample selection method which gave us a sample size of 212 with an error limit of 5\%. The sample distribution per group was determined using Bourley population allocation by applying the formula (see Creswell, 2007):

$$
G S_{s}=\frac{P_{G} * R S_{S}}{N}
$$

Where:

$\mathrm{GS}_{\mathrm{s}}=$ group sample size; $\mathrm{P}_{\mathrm{G}}=$ population of group; $\mathrm{RS}_{\mathrm{s}}=$ required sample size; and $\mathrm{N}=$ population of the study.

Table 1 below presents the population and sample distribution among the respondent groups. The distribution to key respondent groups is: Profession accountants-160; accounting lecturers-32, Postgraduate accounting students-20, giving a total of 212 respondents. The non-probability purposive sampling technique was used in sample selection; participants were chosen based on their depth of knowledge in accounting education and practice. 
Table 1. Population and sample distribution

\begin{tabular}{lccc}
\hline Population Group & Total Population & Sample Distribution & Percentage of Sample \\
\hline Professional Accountants & 340 & 160 & 75.5 \\
Accounting Lecturers & 68 & 32 & 15.1 \\
Postgraduate Accounting Students & 42 & 20 & 9.4 \\
Total & $\mathbf{4 5 0}$ & $\mathbf{2 1 2}$ & $\mathbf{1 0 0}$ \\
\hline
\end{tabular}

\subsection{Sources of Data and Instruments of Data Collection}

The study used both primary and secondary data. The primary data were obtained with the aid of standard structured questionnaire which was designed to address the research questions for the study. The questions solicited the respondents views on a number of corporate governance and earnings management related issues which cumulatively led to the conjectures about the determinants of unethical financial reporting. The questions were made up of Likert scales ("strongly agree" to "strongly disagree"), numerical rating scales. The study further employed personal interviews to obtain additional information on the specific areas that the questionnaire instrument could not cover. Secondary data were extracted from books, journals, and other publications related to the subject matter.

\subsection{Validation and Reliability of Instrument}

Validity tests were carried out to check the ability of the research instrument to measure the variable it was intended to measure. Both face and content validity tests were conducted and the results were found satisfactory. To ensure stability, dependability and predictability of the research instrument, reliability tests were conducted to determine if the scale consistently reflected the construct it measured using the Cronbach's alpha method. A pilot test was carried out using 10 copies of the instrument in Benue State University, Makurdi. The overall Cronbach's coefficient alpha for the determinants of unethical financial reporting was .934 which is within the range of 0.92 reported by Loebbecke, Eining and Willingham (1989). This suggests that the research instruments used in this study are within acceptable limits in extant empirical literature.

\subsection{Variable Specification and Coding}

This study adopted some of the variables and the model used by Loebbecke, Eining and Willingham (1989). The Loebbecke, Eining and Willingham model sought to help auditors assess the likelihood of financial statement fraud occurrence, whereas the purpose of this research model is to explore the determinants of unethical financial reporting. This implies that only those variables that explain the determinants of unethical financial reporting were used. The modified model used in this study has 8 variables for the determinants as described in Table 2 below.

Table 2. Modified proxies for the determinants of unethical financial reporting

\begin{tabular}{clc}
\hline S/No. & Determinant Proxy & Code \\
\hline 1 & Undue emphasis on meeting earnings targets & $\alpha_{1}$ \\
2 & Compensation/ bonus incentive & $\alpha_{2}$ \\
3 & Part-ownership by management & $\alpha_{3}$ \\
4 & Weak corporate governance & $\alpha_{4}$ \\
5 & Attempts to meet regulatory requirement & $\alpha_{5}$ \\
6 & Attempts to conceal the company's deteriorating financial condition & $\alpha_{6}$ \\
7 & Attempts to increase stock price & $\alpha_{7}$ \\
8 & Attempts to bolster financial performance for pending equity or debt financing & $\alpha_{8}$ \\
\hline
\end{tabular}

Source: Adopted, with modifications, from Loebbecke, Eining \& Willingham (1989).

\subsection{Data Analysis Techniques}

The data collected for this study was analyzed using both descriptive and inferential statistics. The descriptive 
method was employed to describe the demography of respondents and other variables in the study using percentages, frequency count, mean and standard deviation. The formulated hypotheses for the study were tested using the non-parametric Kruskal-Wallis $H$ test and Mann-Whitney $U$ test, using the application package SPSS version 20. The Kruskal-Wallis $H$ test is captured in the following equation:

$$
r=\frac{12}{\alpha(\alpha+1)} \sum_{i=1}^{k} \frac{R_{i}^{2}}{\alpha_{i}}-3(\alpha+1)
$$

Where $\alpha i=\alpha_{1}+\alpha_{2}+\ldots+\alpha_{k}$ (the proxies for the determinants of unethical financial reporting), and $\mathrm{R}_{\mathrm{i}}^{2}=$ the sum of the ranks assigned to $\alpha_{\mathrm{i}}$ observations in the dataset.

\section{Results and Discussion}

The starting point for this section is the analysis of usable survey, followed by respondents' characteristics and data analysis and results.

\subsection{Return for Usable Survey}

Table 3 contains the summary of distributed and retrieved copies of the questionnaire instrument. A total of 212 copies of the questionnaire were distributed: 160 copies to Professional Accountants, 32 copies to Accounting Lecturers, and 20 to Accounting Postgraduate Students. Out of this, a total of 173 copies (representing $81.6 \%$ of the distributed instruments) were retrieved, but after sorting the copies of the retrieved instruments, the return for usable survey was found to be 165 copies (representing $77.8 \%$ ). The 165 copies formed the basis for primary data analysis.

Table 3. Response to questionnaire

\begin{tabular}{lcccccc}
\hline \multirow{2}{*}{ GROUP } & \multicolumn{2}{c}{ Distribution } & \multicolumn{2}{c}{ Retrieved } & \multicolumn{2}{c}{ Usable } \\
\cline { 2 - 7 } & No. & \% & No. & \% & No. & \% \\
\hline Professional Accountants & 160 & 75.5 & 121 & 57.1 & 113 & 53.3 \\
Accounting Lecturers & 32 & 15.1 & 32 & 15.1 & 32 & 15.1 \\
Accounting Postgraduate Students & $\underline{20}$ & $\underline{9.4}$ & $\underline{20}$ & $\underline{9.4}$ & $\underline{20}$ & $\underline{9.4}$ \\
TOTAL & $\mathbf{2 1 2}$ & $\mathbf{1 0 0}$ & $\mathbf{1 7 3}$ & $\mathbf{8 1 . 6}$ & $\mathbf{1 6 5}$ & $\mathbf{7 7 . 8}$ \\
\hline
\end{tabular}

\subsection{Sample Characteristics}

Table 4 shows the profile of respondents. Panel A of the table indicates that 131(79.4\%) of the respondents are males, while $34(20.6 \%)$ are females giving a total of 165 . The female minority is as a result of Nigerian culture and religious beliefs which discourage females from receiving western education and taking up white collar jobs. However, the wide differential in the sex of respondents does not have statistical significance on the result because the questions are not gender sensitive. Panel B presents the respondents in their groups which include 113(68.5\%) Professional Accountants, 32(19.4\%) Accounting Lecturers, and 20(12.1\%) Accounting Postgraduate Students.

Table 4. Profile of respondents

\begin{tabular}{lccc}
\hline Item & Frequency & Percentage (\%) & Cumulative (\%) \\
\hline Panel A: SEX & 131 & 79.4 & 79.4 \\
Male & $\underline{34}$ & $\underline{20.6}$ & 100 \\
Female & $\mathbf{1 6 5}$ & $\mathbf{1 0 0}$ & \\
Total & & & 68.5 \\
\hline Panel B: GROUP & 113 & 68.5 & 87.9 \\
Professional Accountants & 32 & 19.4 & 100 \\
Academics Accountants & $\underline{20}$ & $\underline{12.1}$ & \\
Accounting Postgraduate Students & $\mathbf{1 6 5}$ & $\mathbf{1 0 0}$ & \\
Total & & & \\
\hline
\end{tabular}




\subsection{Inferential Analyses}

In order to assess the severity of the overall perceived determinants of unethical financial reporting among accounting practitioners and academics, a multinomial logistic regression was carried out with the subject views as the dichotomous criterion variable and the category of each subject (professional accountant $=1$, accounting lecturers $=2$, and accounting postgraduate students $=3$ ) as the predicator variable. The independent variables were coded so that odds ratio (ORs) larger than 1 was associated with the greater likelihood of severer determinant outcome, while ORs less than 1 meant that the proxy was associated with a lesser likelihood of severity. In order to facilitate comparison of the dimensions of severity without compromising the precision of the Likert scale, the sub-scales were split into dichotomous variables representing 'low severity' and 'high severity'. The dichotomous variables were created such that the two Likert points at the upper end of the severity range were re-coded as 'high severity', while the 3 Likert points at the other end were re-coded as 'low severity'. The choice of this cutoff is similar to the procedure described by Hall and Dorman (1988). That is recoded scores of 1,2,3 were defined as 'low' while recoded scores of 4 or 5 were defined as 'high' on each proxy subscale. Percentages of low and high severities on each of the subscale (proxy) were then calculated and compared between the 3 groups. In order to reduce the number of tables, bivariate analysis of individual items are not presented here, only the predicators of the overall determinants are presented.

\subsection{Results}

Table 5 presents the predicators of the overall general determinants of unethical financial reporting and their level of significance. The proxy $\alpha_{4}$; 'weak corporate governance' is significantly likeliest to be the severest determinant of unethical financial reporting with the highest odds ratio $(\mathrm{OR}=2.01 ; 95 \% \mathrm{CI}=0.91-4.84 ; \mathrm{p}<$ 0.001). This means that it has the odds of being 2.01 times severer than otherwise; it is also significant at the $1 \%$ level. This is followed by $\alpha_{6}$; 'attempts to conceal company's deteriorating financial position' as the next significantly likelier determinant $(\mathrm{OR}=1.83 ; 95 \% \mathrm{CI}=1.20-3.19 ; \mathrm{p}<0.001)$, it also has a 1.83 times odds of being severer than otherwise and this is significant at the $1 \%$ level too. The third determinant in order of severity is $\alpha_{2}$; 'compensation and bonus incentives' ( $\left.\mathrm{OR}=1.72 ; 95 \% \mathrm{CI}=1.13-2.72 ; \mathrm{p}=0.010\right)$ with 1.72 time odds of being severer than otherwise. This determinant is also significant at the $1 \%$ level. The determinant with the least likelihood of severity based on the considerations of professional and academic accountants is $\alpha_{8}$; 'attempts to bolster financial performance for pending equity or debt financing' $(\mathrm{OR}=0.41 ; 95 \% \mathrm{CI}=0.20-1.33 ; \mathrm{p}=0.061)$. This determinant is, however, not statistically significant.

Table 5. Adjusted odds ratio of the predicators of the overall determinants of unethical financial reporting

\begin{tabular}{lccc}
\hline Proxy & Odds ratio & 95\% confidence interval & p-value \\
\hline$\alpha_{1}$ & 0.55 & $0.31-1.11$ & $0.097^{*}$ \\
$\alpha_{2}$ & 1.72 & $1.13-2.72$ & $0.010^{* * *}$ \\
$\alpha_{3}$ & 0.44 & $0.21-1.03$ & 0.111 \\
$\alpha_{4}$ & 2.01 & $0.91-4.84$ & $0.001^{* * *}$ \\
$\alpha_{5}$ & 0.56 & $0.38-1.22$ & 0.107 \\
$\alpha_{6}$ & 1.83 & $1.20-3.19$ & $0.001^{* * *}$ \\
$\alpha_{7}$ & 1.03 & $0.09-1.72$ & $0.084^{*}$ \\
$\alpha_{8}$ & 0.41 & $0.20-1.33$ & $0.061^{*}$ \\
\hline
\end{tabular}

Note. *** Significant at $1 \% ; *$ Significant at $10 \%$.

The Kruskal -Wallis $H$ test was carried out to ascertain whether differences existed in the views of Professional Accountants and Academic Accountants (Lecturers and Postgraduate Students) on what determines unethical financial reporting. The first part of the Kruskal -Wallis $H$-test results is presented in Table 6. The results show the mean rank of the overall perceptions of Professional and Academic Accountants on the determinants of unethical financial reporting. Professional Accountants have the least overall perceptions on the determinants of unethical financial reporting (mean rank $=713.76$ ), followed by Accounting Postgraduate Students (mean tank =759.12). Accounting Lecturers have the highest overall view of the determinants of unethical financial reporting (mean rank $=835.93$ ). The test statistics report a chi-square $\left(\mathrm{X}^{2}\right)$ value of 20.643 , with an associated probability $(\mathrm{P})$ value of less than 0.01 . It can be concluded that there are significant differences in the overall views of Professional and Academic Accountants on the determinants of unethical financial reporting. 
Table 6. Kruskal-Wallis $H$ test on differences in the views of the respondent groups

\begin{tabular}{lcc}
\hline Panel A: Respondent Groups & No. of Ranks & Mean Rank \\
\hline Professional Accountants & 1017 & 713.76 \\
Accounting Lecturers & 289 & 835.93 \\
Accounting Postgraduate Students & $\underline{179}$ & 759.12 \\
Total & $\mathbf{1 4 8 5}$ & \\
\hline Panel B: Test Statistics & \multicolumn{3}{c}{20.643} \\
\hline Chi-Square & 2 & \\
Df & \multicolumn{2}{c}{0.000} \\
Asymp. Sig & & \\
\hline
\end{tabular}

Since significant differences exist between the respondents (Professional Accountants, Accounting Lecturers, and Accounting Postgraduate Students), the adjusted odds ratio analysis was used to identify the specific areas of differences. Tables 7a-c present the adjusted odds ratio of the determinants (predicators) of unethical financial reporting based on the perceptions of the groups. Among Professional Accountants, the proxy $\alpha_{2}$; 'compensation and bonus incentives' is significantly considered as the likeliest severest determinant of unethical financial reporting with the highest odds ratio $(\mathrm{OR}=2.34 ; 95 \% \mathrm{CI}=1.50-3.65 ; \mathrm{p}<0.001)$. On the other hand, Accounting Lecturers consider the proxy $\alpha_{4}$ : 'weak corporate governance' $(\mathrm{OR}=2.19 ; 95 \% \mathrm{CI}=1.31-2.13 ; \mathrm{p}=0.001)$ as the severest predicator. This view is also shared by Accounting Postgraduate Students who consider the same $\alpha_{4}$ : 'weak corporate governance' $(\mathrm{OR}=2.69 ; 95 \% \mathrm{CI}=1.35-5.36 ; \mathrm{p}=0.001)$ as the severest predicator of unethical financial reporting.

Professional Accountants consider $\alpha_{4}$; 'weak corporate governance' $(\mathrm{OR}=1.89 ; 95 \% \mathrm{CI}=1.11-3.27 ; \mathrm{p}<0.001)$ as the second significantly likelier determinant of unethical financial reporting. However, the determinant considered the second severer in the views of Accounting Lecturers is $\alpha_{6}$ : 'an attempt to conceal the company's deteriorating financial condition' with values of $(\mathrm{OR}=2.10 ; 95 \% \mathrm{CI}=0.91-4.37 ; \mathrm{p}<0.004)$. Accounting Postgraduate Students, however, consider the proxy $\alpha_{2}$; 'compensation and bonus incentives' as the second severer determinant of unethical financial reporting. The predictors for both Professional Accountants and Accounting Postgraduate Students are significant at the $1 \%$ level.

Professional Accountants and Accounting Postgraduate Students have the same views with regards to the third severer predicator of unethical financial reporting. This predicator is $\alpha_{6}$; 'attempts to conceal the company's deteriorating financial condition'; with values of $(\mathrm{OR}=1.68 ; 95 \% \mathrm{CI}=0.97-2.91 ; \mathrm{p}=0.063)$ and $(\mathrm{OR}=1.70$; 95\% CI $=1.13-2.56 ; \mathrm{p}=0.010$ ). This predictor is not significant at the 5\% level for Professional Accountants but significant at $1 \%$ level for Accounting Postgraduate Students. Accounting Lecturers, on the other hand, view $\alpha_{2}$; 'compensation and bonus incentives' $(\mathrm{OR}=1.52 ; 95 \% \mathrm{CI}=0.71-2.23 ; \mathrm{p}=0.084)$ as the third severer predicator of unethical financial reporting, but this predictor is not significant at the $5 \%$ level.

Table 7a. Adjusted odds ratio of determinants of unethical financial reporting

\begin{tabular}{llcl}
\hline Proxy & \multicolumn{2}{c}{ Professional Accountants } \\
\hline & Odds ratio & 95\% confidence interval & p-value \\
\hline$\alpha_{1}$ & 0.47 & $0.20-1.09$ & $0.097^{*}$ \\
$\alpha_{2}$ & 2.34 & $1.50-3.65$ & $0.001^{* * *}$ \\
$\alpha_{3}$ & 0.46 & $0.18-1.18$ & 0.106 \\
$\alpha_{4}$ & 1.89 & $1.11-3.27$ & $0.001^{* * *}$ \\
$\alpha_{5}$ & 0.52 & $0.23-1.18$ & 0.115 \\
$\alpha_{6}$ & 1.68 & $0.97-2.91$ & $0.063^{*}$ \\
$\alpha_{7}$ & 1.03 & $0.51-2.06$ & 0.963 \\
$\alpha_{8}$ & 0.27 & $0.07-1.13$ & $0.075^{*}$ \\
\hline
\end{tabular}

Note. $* * *$ Significant at $1 \% ; *$ Significant at $10 \%$. 
Table 7b. Adjusted odds ratio of determinants of unethical financial reporting

\begin{tabular}{llcl}
\hline Proxy & \multicolumn{3}{c}{ Accounting Lecturers } \\
\hline$\alpha_{1}$ & Odds ratio & 95\% confidence interval & p-value \\
$\alpha_{2}$ & 0.43 & $0.17-1.06$ & $0.066^{*}$ \\
$\alpha_{3}$ & 1.52 & $0.71-3.23$ & $0.063^{*}$ \\
$\alpha_{4}$ & 0.38 & $0.12-1.08$ & 0.111 \\
$\alpha_{5}$ & 2.19 & $1.31-2.13$ & $0.001^{* * *}$ \\
$\alpha_{6}$ & 0.52 & $1.30-3.22$ & 0.407 \\
$\alpha_{7}$ & 2.10 & $0.91-4.37$ & $0.004^{* *}$ \\
$\alpha_{8}$ & 1.22 & $0.75-2.01$ & $0.084^{*}$ \\
\hline
\end{tabular}

Note. $* * *$ Significant at $1 \% ; * *$ Significant at $5 \% ; *$ Significant at $10 \%$.

Table 7c. Adjusted odds ratio of determinants of unethical financial reporting

\begin{tabular}{llcl}
\hline & \multicolumn{3}{c}{ Accounting Postgraduate Students } \\
\hline Proxy & Odds ratio & 95\% confidence interval & p-value \\
\hline$\alpha_{1}$ & 1.22 & $0.62-2.42$ & 0.497 \\
$\alpha_{2}$ & 1.86 & $1.09-3.17$ & $0.055^{* *}$ \\
$\alpha_{3}$ & 0.52 & $1.23-2.88$ & 0.111 \\
$\alpha_{4}$ & 2.69 & $1.35-5.36$ & $0.001^{* * *}$ \\
$\alpha_{5}$ & 0.52 & $1.30-3.22$ & 0.407 \\
$\alpha_{6}$ & 1.70 & $1.13-2.56$ & $0.010^{* * *}$ \\
$\alpha_{7}$ & 1.05 & $0.77-1.44$ & 0.784 \\
$\alpha_{8}$ & 0.32 & $0.15-0.77$ & $0.009^{*}$ \\
\hline
\end{tabular}

Note. *** Significant at 1\%; ** Significant at 5\%; * Significant at 10\%.

Further analysis was carried out to ascertain whether significant differences exist between the views of Professional Accountants and Accounting Lecturers on what constitute unethical financial reporting. The exclusion of Accounting Postgraduate Students from this further analysis is to ensure that only the opinions of key stakeholders that could influence decision making in this respect are considered. Post hoc tests between the groups were conducted using Mann-Whitney U-test for observable latent differences.

Table 8 shows the mean rank and the test statistics on the views of Professional Accountants and Accounting Lecturers on the determinants of unethical financial reporting. Accounting Lecturers have a higher mean rank (737.49) than Professional Accountants (629.63). The test statistics show a $Z$ value of -4.526 , which is significant at a p-value of less than $1 \%$. The results suggest that there are significant differences in the views of Professional Accountants and Accounting Lecturers on the determinants of unethical financial reporting. Accounting Lecturers have a significantly higher view on the determinants of unethical financial reporting than professional accountants.

Table 8. Mann-Whitney determinants post hoc test on differences in the views of professional accountants and accounting lecturers

\begin{tabular}{|c|c|c|c|c|}
\hline & \multirow[b]{2}{*}{ Group } & \multicolumn{3}{|c|}{ Ranks } \\
\hline Panel A: & & No. & Mean Rank & Sum of Ranks \\
\hline \multicolumn{2}{|c|}{ Professional Accountants } & 1017 & 629.63 & 640336.00 \\
\hline \multicolumn{2}{|c|}{ Accounting Lecturers } & 289 & 737.49 & 213135.00 \\
\hline \multicolumn{2}{|l|}{ Total } & 1306 & & \\
\hline \multicolumn{5}{|c|}{ Panel B: Test Statistics } \\
\hline \multirow[t]{2}{*}{ Mann-Whiteney } & $U$ & \multicolumn{3}{|c|}{122683.000} \\
\hline & $\mathrm{Z}$ & \multicolumn{3}{|c|}{-4.526} \\
\hline \multicolumn{2}{|c|}{ Asymp. Sig. (2-tailed) } & \multicolumn{3}{|c|}{.000} \\
\hline
\end{tabular}




\subsection{Discussion of Results}

\subsubsection{Severity of the Determinants of Unethical Financial Reporting}

The first objective of this study was to ascertain, in order of severity, what Professional and Academic Accountants perceive are the main causes of unethical behavior exhibited by accountants in financial reporting. The result indicates that 'weak corporate governance' is perceived overall, as the severest determinant of unethical financial reporting. This study's identification of weak corporate governance as the severest of the determinants of unethical financial reporting is consistent with anecdotal evidence which associates the causes of a number of corporate crises and failures to this factor. For instance, the collapse of Enron was due to its boards failure to effectively monitor its operations, while the Afribank Plc case and Cudbury Nigeria Plc crises emanated from corporate governance failings as well (Jetuah, 2007; Onu, 2007).

The second determinant perceived as the next severer is 'attempts to conceal deteriorating financial position'. This determinant has also featured prominently in the works of Payne and Robb (2000), and Roychowdhury (2006) which have supported the use of fraudulent financial reporting as a means towards the avoidance of reporting losses or decreasing financial performance. The third determinant in order of severity is 'compensation and bonus incentive'. Healy (1985) first found that managers have an economic incentive to manipulate financial report in order to increase their cash compensation. He concluded that there is a strong association between accruals and managers' income-reporting incentives under a management bonus plan. This study's results relating to compensation is also consistent with the evidence provided by Leuz, Nanada, and Wysocki (2003) which suggest that managerial opportunistic behavior including excessive compensation for managers is ultimately reflected in the firm's earnings misstatement.

\subsubsection{Comparison of Respondents Views on the Determinants of Unethical Financial Reporting}

The second objective of the study was to find out if significant differences exist between the views of professional and academic accountants (Accounting Lecturers and Accounting Postgraduate Students) regarding the determinants of unethical financial reporting. The overall results showed significant differences in the views of the respondents on the determinants of unethical behavior in financial reporting. The results of a Mann-Whitney U test comparing the views of each pair of respondents' suggest that significant differences exist between the views of Professional Accountants and Accounting Lecturers on what determines unethical financial reporting.

Lack of agreement between the views of Professional Accountants and Accounting Lecturers, however, acerbates academic research challenges; it also complicates policy formulation and implementation with respect to how to curb the incidence of unethical financial reporting. The study alludes to the dire need for academics and practitioners to cart a common path: the academic providing the necessary foundation upon which practice is nurtured; the practitioner drawing on theories and guidance provided by the academic for resolution of practical issues in accounting. Conclusively, the divergence in views on what constitute unethical financial reporting adumbrates the likely problems to be encountered when policies addressing governance issues on unethical financial reporting are tabled for discussion.

\section{Conclusion and Recommendation}

\subsection{Conclusion}

This study examined the determinants of unethical financial reporting from the viewpoints of professional and academic accountants (Accounting Lectures and Accounting Postgraduate Students) using Nigerian sample. It also sought to ascertain whether there are significant differences between the views expressed by the respondent groups on what determines unethical financial reporting. The evidence generated from the study leads to two major conclusions. First, there is consensus amongst the respondents that 'weak corporate governance' is the severest determinant of unethical financial reporting. This is followed by 'attempts to conceal deteriorating financial position' and then 'compensation and bonus incentives' in diminishing order of severity. The determinant with the least odds of severity was identified as 'attempts to bolster financial performance for pending equity or debt financing'. Second, the views of Professional Accountants and Accounting Lecturers on the phenomenon of interest were significantly different. The perception of Accounting Lecturers was significantly higher than that of Professional Accountants.

\subsection{Recommendations}

Based on the findings of this study, two recommendations are made. First, the study recommends incorporation of good corporate governance in the overall strategies of corporations to improve ethical behavior in financial reporting. This can be achieved by a clear articulation of the organization's ethical standards in a set of core 
values and a formal code of conduct that holds all personnel strictly accountable for compliance with the code and enforcement of discipline for violations consistently across all levels of the organization. Second, the study recommends speedy implementation of international standards in financial reporting, such as International Financial Reporting Standards (IFRS) and International Public Sector Accounting Standards (IPSAS) that have the potentials to curtail or discourage unethical financial reporting.

\section{References}

Achua, J. K. (2009). Reinventing governmental accounting for accountability assurance in Nigeria. Nigeria Research Journal of Accountancy, 1(1), 1-16.

Aguolu, O. (2006). Ethics and integrity in the accounting profession. The Nigerian Accountant, 39(4), 31-34.

Akpa, A. (2011). Knowledge creation process: Concepts and applications in social science. Makurdi: Aboki Publishers.

Albrecht C. O. (2008). International fraud: A management perspective (Doctoral Thesis). Institute for Labour Studies. Retrieved from http://www.tdx.cat/bitstream/handle/10803/9196/ALBRECHT_Tesis_Abril_2008.pdf;jsessionid=E6D7B79 3DC20542302C57B833E4A33BC.tdx1?sequence=1

Beasley, M. S., Carcello, J. V., \& Hermanson, D. R. (1999). Fraudulent financial reporting 1987-1997: An analysis of U.S. public companies. New York: American Institute of Certified Public Accountants. Retrieved from http://www.coso.org/publications/ffr_1987_1997.pdf

Chao, F., \& Tan, K. (2007). "American Dream" theory of corporate executive fraud. Accounting Forum, 31, 203-215. http://dx.doi.org/10.1016/j.accfor.2006.12.004

Cohen, J. R., \& Holder-Webb, L. L. (2006). Rethinking the influence of agency theory in the accounting academy. Issues in Accounting Education, 21(1), 17-39. http://dx.doi.org/10.2308/iace.2006.21.1.17

Cressey, D. R. (1953). Other People's Money: A Study in the Social Psychology of Embezzlement. New York, NY, US: Free Press. Retrieved from http://psycnet.apa.org/psycinfo/1954-06293-000

Deakin, S., \& Konzelmann, S. J. (2004). Learning from enron. Corporate Governance, 12(2), 134-142. http://dx.doi.org/10.1111/j.1467-8683.2004.00352

Enderle, G. (2004). Global competition and corporate responsibilities of small and medium-sized enterprises. Business Ethics-A European Review, 13, 51-63. http://dx.doi.org/10.1111/j.1467-8608.2004.00349.x

Fama, E. F., \& Jensen, M. C. (1983). Separation of ownership and control. Journal of Law and Economics, 26, 301-325. http://dx.doi.org/10.1086/467037

Garner, B. A. (2004). Black's law dictionary (8th ed.). St. Paul, MN: Thompson-West. Retrieved from http://www.amazon.com/Blacks-Law-Dictionary-Edition-Standard/product-reviews/0314151990

Giacomino, D. E., \& Akers, M. (2006). The ethics of managing short-term earnings: Business managers and business students rate earnings management practices-implications for academia. Journal of College Teaching \& Learning, 57-71. $\quad$ Retrieved from http://www.researchgate.net/publication/228731853_The_ethics_of_managing_short-term_earnings_busine ss_managers_and_business_students_rate_earnings_management_practicesimplications_for_academia

Hall, J., \& Dorman, M. (1988). Meta-analysis of satisfaction with medical care: Description of research domain and analysis of overall satisfaction levels. Soc. Sci. Med., 27(6), 637-644. http://dx.doi.org/10.1016/0277-9536(88)90012-3

Healy, P. M. (1985). Impact of bonus schemes on the selection of accounting principles. Journal of Accounting and Economics, 85-107. http://dx.doi.org/10.1016/0165-4101(85)90029-1

Heath, J., \& Norman, W. (2004). Stakeholder theory, corporate governance and public management: What can the history of state-run enterprises teach us in the post-Enron era? Journal of Business Ethics, 53, 247-265. http://dx.doi.org/10.1023/B:BUSI.0000039418.75103.ed

Herbert, W. E., \& Tsegba, I. N. (2013). Economic consequences of international financial reporting standards (IFRS) adoption: Evidence from a developing country. European Journal of Business and Management, 5(28), 80-99. Retrieved from http://www.iiste.org/Journals/index.php/EJBM/article/viewFile/8721/9007

Jensen, M. C. (2001). Value maximization, stakeholder theory, and the corporate objective function. Social Science Research Network, Electronic Library. http://dx.doi.org/10.1111/j.1745-6622.2001.tb00434.x 
Jetuah, D. (2007). Cadbury auditor steps down by mutual agreement'. Retrieved from http://www.accountancyage.com/aa/news/1777200/cadbury-auditor-steps-mutual-agreement

Johnson, S., Ryan, H., \& Tian, Y. (2009). Managerial incentives and corporate fraud: The sources of incentives matter. Review of Finance, 13, 115-145. http://dx.doi.org/10.1093/rof/rfn014

Kay, J., \& Silberston, A. (1995). Corporate governance. National Institute of Economic Review, 153, 84-111. http://dx.doi.org/10.1177/002795019515300107

Leuz, C., Nanda, D., \& Wysocki, P. D. (2003). Earnings management and investor protection: An international $\begin{array}{lllll}\text { comparison. Journal of } & \text { Financial } & \text { Economics, } & 69, & \text { 505-527. }\end{array}$ http://dx.doi.org/10.1016/S0304-405X(03)00121-1

Loebbecke, J. K., Eining, M. M., \& Willingham, J. J. (1989). Auditors' experience with material irregularities: Frequency, nature, and detectability. Auditing: A Journal of Practice \& Theory, 9(1), 1-28.

Lowenstein, G., \& Rick, S. (2008). Hyper-motivations. Journal of Marketing. Retrieved from http://gbo.wharton.upenn.edu/document/opinion/research/hypermotivation.pdf

Luhman, H., \& Cuniffe, E. (2012). Agency theory: An assessment and review. Academy of Management Review, 42, 12-43. Retrieved from http://www.sagepub.com/upm-data/49945_Luhman_\&_Cunliffe_Chapter_One.pdf

Mulford, C. W., \& Comiskey, E. E. (2002). The financial numbers game: Detecting creative accounting practices. New York: John Wiley \& Sons Inc.

National Association of Certified Fraud Examiners (NACFE). (1993). Cooking the books: What every accountant should know about fraud. No. 92-5401 Self-Study Workbook 12.

Nwagboso, J. (2008). Professional ethics, skill and standards. Jos: Inspiration Media.

Obazee, J. O. (2005). Standardization of financial reporting at the federal, state and local government levels. The Nigerian Accountant, 38(1), 17-32.

Olalere, T. (2010). Methodology in accounting research: A critique of taxonomy. Retrieved from http://ssrn.com/abstract=1921192

Onu, E. (2007). Akintola williams deloitte: Battling confidence crisis. BusinessWeek, March 4.

Payne, J., \& Robb, S. (2000). Earnings management: The effect of ex ante earnings expectations. Journal of Accounting, Auditing and Finance, 72(4), 153-186. http://dx.doi.org/10.1177/0148558X0001500401

Rezaee, Z. (2009). Financial statement fraud: Prevention and detection (2nd ed.). New York: John Wiley \& Sons, Inc. Retrieved from http://eu.wiley.com/WileyCDA/WileyTitle/productCd-0470455705.html

Roychowdhury, S. (2006). Earnings management through real activities manipulation. Journal of Accounting and Economics, 42, 335-370. http://dx.doi.org/10.1016/j.jacceco.2006.01.002

Skousen, C. J., Smith, R. K. P., \& Wright, C. J. (2009). Detecting and predicting financial statement fraud: The effectiveness of the fraud triangle and SAS No. 99. Corporate Governance and Firm Performance Advance in Financial Economics, 13, 53-58. http://dx.doi.org/10.2139/ssrn.1295494

Soltani, B. (2009). A closer look at financial reporting: Understanding the fraud risks associated with corporate reporting is vital to maintaining organizational well-being. Retrieved from http://www.thefreelibrary.com

Sutherland, E. H. (1949). White-collar crime. New York: Dryden Press. Retrieved from http://www.asanet.org/images/asa/docs/pdf/1939\%20Presidential\%20Address\%20\%28Edwin\%20Sutherlan d\%29.pdf

Vanasco, R. R. (1998). Fraud auditing. Managerial Auditing Journal, 13(1), 4-71. http://dx.doi.org/10.1108/02686909810198724

Wolf, D., \& Hermanson, D. (2004). The fraud diamond: Considering the four elements of fraud. The CPA Journal, December, 34-37. Retrieved from http://wweb.uta.edu/faculty/subraman/EMBA-FTW2009/Articles/Fraud\%20Diamond\%20Four\%20Element s.CPAJ2004.pdf 


\section{Copyrights}

Copyright for this article is retained by the author(s), with first publication rights granted to the journal.

This is an open-access article distributed under the terms and conditions of the Creative Commons Attribution license (http://creativecommons.org/licenses/by/3.0/). 